\title{
A new species of Xysticus C.L. Koch, 1835 (Aranei: Thomisidae) from South Siberia
}

\author{
Новый вид пауков Xysticus C.L. Koch, 1835 (Aranei: Thomisidae) \\ из Южкной Сибири
}

\author{
Alexander A. Fomichev ${ }^{1,2}$, Yuri M. Marusik ${ }^{3}$ and Seppo Koponen ${ }^{4}$ \\ А.А. Фомичев ${ }^{1,2}$, Ю.М. Марусик ${ }^{3}$, С. Копонен ${ }^{4}$

\footnotetext{
${ }^{1}$ Novosibirsk State Pedagogical University, Vilyuiskaya 28, Novosibirsk 630126, Russia. E-mail: a.fomichov@mail.ru

${ }^{2}$ Institute of Systematics and Ecology of Animals, SB RAS, Frunze str., 11, Novosibirsk 91, 630091, Russia.

${ }^{3}$ Institute of Biological Problems of the North, RAS, Portovaya Str. 18, Magadan 685000, Russia. E-mail: yurmar@mail.ru

${ }^{4}$ Zoological Museum, University of Turku, FI-20014 Turku, Finland.

${ }^{1}$ Новосибирский государственный педагогический университет, Вилюйская 28, Новосибирск 630126, Россия.

${ }^{2}$ Институт систематики и экологии животных, СО РАН, Фрунзе 11, Новосибирск 91, 630091.

${ }^{3}$ Институт биологических проблем Севера ДВО РАН, Портовая 18, Магадан 685000.
}

KEY WORDS: Altai, China, Russia, Tuva, Xinjiang, spider, Aranei.

КЛЮЧЕВЫЕ СЛОВА: Алтай, Китай, Россия, Синьцзян, Тува, паук, Aranei.

ABSTRACT. A new species, Xysticus lehtineni sp.n., is described from South Siberia on the basis of both sexes. It is closely related to $X$. baltistanus $(\mathrm{Ca}-$ poriacco, 1935) known from northern Pakistan to northeastern Asia. The two species clearly differ in size, abdominal pattern, spination and in the shape of the copulatory organs (male palp and female epigyne). Most of the records of $X$. baltistanus from Tuva refer to this new species.

РЕЗЮМЕ. Из Южной Сибири по обоим полам описан Xysticus lehtineni sp.n. Новый вид близок к $X$. baltistanus (Caporiacco, 1935), известному от Ceверного Пакистана до Чукотки. Виды различаются размером, шипованием, окраской брюшка и формой совокупительных органов. Большинство указаний $X$. baltistanus из Тувы относятся к новому виду.

\section{Introduction}

Thomisidae is one of the best studied families of spiders in Siberia as a whole, and particularly in the Altai Mountains and adjacent Tuva, Mongolia and Xinjiang. Crab spiders have been surveyed in several taxonomic papers: Logunov [1995], Logunov \& Marusik [1994, 1998], Marusik \& Logunov [1990, 1995, 2002], Marusik et al. [2007] and in many faunistic publications.

Altogether about 45 species of crab spiders have been reported from the Altai. Most of them (25) belong to Xysticus C.L. Koch, 1835 (personal data). While studying spiders in the Altai, the senior author found numerous females thought to belong to $\mathrm{X}$. bal- tistanus (Caporiacco, 1935), a species known from northern Pakistan to Chukotka (northeastern Asia) [Marusik et al., 2000]. However, the discovery of the conspecific male from the Altai revealed that it represents an undescribed species, which differs from $X$. baltistanus by its larger size, abdominal pattern in males and females, and also by the shape of the male palp. The goal of this paper is to provide a detailed description of the new species and to compare it with $X$. baltistanus.

\section{Material and methods}

Photographs were taken using an Olympus E-520 camera attached to an Olympus SZX16 stereomicroscope, and prepared using CombineZP image stacking software. Epigynes were cleared in a $\mathrm{KOH} /$ water solution. Photographs were taken with the specimens secured in dishes with paraffin on bottom. Lengths of leg segments were measured on the dorsal side. All measurements are given in millimetres.

While describing spination, the apical spines on the metatarsi were not counted. In cases of variation, the alternative spination is given in brackets. The following abbreviations are used in the text: Leg segments: $\mathrm{Fe}$ - femur, $\mathrm{Pa}$ - patella, Mt - metatarsus, Ta tarsus, Ti - tibia. Spination: $\mathrm{d}$ - dorsal, $\mathrm{p}$ - prolateral, $\mathrm{r}$ - retrolateral, $\mathrm{v}$ - ventral. Abbreviations for museums: HUB - Hebei University, Baoding; ISEA Institute for Ecology and Systematic of Animals, Novosibirsk; MMUM - Manchester Museum, the University of Manchester; ZMUT — Zoological Museum, University of Turku, Finland. 


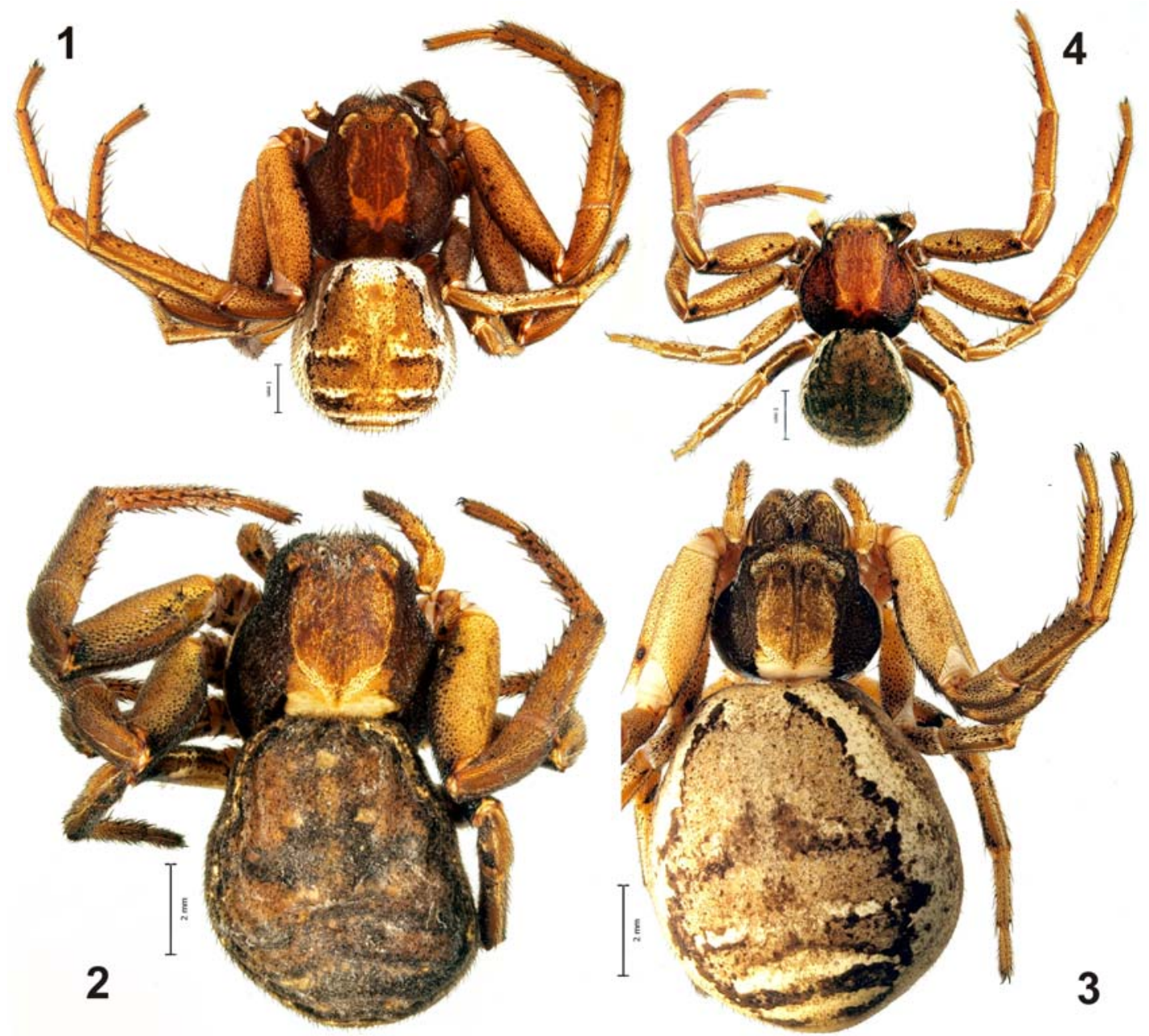

Figs 1-4. Habitus of Xysticus lehtineni sp.n. (1-3, holotype and allotype) and X. baltistanus (4, Xinjiang): 1, 4 - male, dorsal; 2-3 female, dorsal, showing variations of the abdominal pattern.

Pис. 1-4. Габитус Xysticus lehtineni sp.n. (1-3, голотип и аллотип) и X. baltistanus (4, Синьцзян): 1, 4 — самец, сверху; 2-3 самка, сверху, показаны разные варианты окраски брюшка.

\section{Description}

\section{Xysticus lehtineni sp.n.}

Figs 1-3, 5-6, 9-11, 15-18, 21-24, Map 1.

X. baltistanus: Logunov \& Marusik, 1994: 182 (in part); Logunov et al., 1998: 143 (in part); Marusik et al., 2000: 115 (in part); Azarkina \& Trilikauskas, 2013: 250

TYPES. Holotype $\sigma^{7}$ (ISEA), Russia, Altai Republic, KoshAgach District, Chikhacheva Mt. Range, Talduair Massive, Sailyugem Mt. $\left(50^{\circ} 01^{\prime} \mathrm{N} ; 89^{\circ} 14^{\prime} \mathrm{E}\right), 2250-2500 \mathrm{~m}, 20-23.06 .2013$ (S.I. Mishenin). Paratypes: 6 + ㅇ (ISEA, MMUM), together with holotype; 3 우 (ISEA), same locality, $2250 \mathrm{~m}$, mountain stony steppe, 2-5.07.2013 (A.A. Fomichev); 2 우 (ISEA), Sailyugem Mt. Range, $10 \mathrm{~km}$ WSW Tashanta Vil., Bol'shie Shibety valley $\left(49^{\circ} 40^{\prime} \mathrm{N}\right.$; $\left.89^{\circ} 04^{\prime} \mathrm{E}\right), 2300 \mathrm{~m}$, mountain stony steppe with rocky outcrops, 16.07.2009 (A.A. Fomichev); 7 우 (ISEA), Chuiskaya Steppe, Krasnaya Gorka Mt., $4 \mathrm{~km}$ SE from Chagan-Uzun Vil. $\left(50^{\circ} 04^{\prime} \mathrm{N}\right.$; $\left.88^{\circ} 24^{\prime} \mathrm{E}\right), 1800-1900 \mathrm{~m}$, stony semi-desert steppe with rocks, 1900 $2100 \mathrm{~m}$, mountain stony steppe, 23-24.07.2012 (A.A. Fomichev); 1 (ISEA), same locality, 11.07.2013 (A.A. Fomichev); 1 (SZM 001.2537), left riverside of Edigan River, $4 \mathrm{~km}$ upstream of the confluence with Katun' River, ca. 1100 m, dry steppe, 6.07.1998 (A.Li). Tuva: $10^{7}$ (ZMUT), NE shore of Ubsu-Nur Lake, $750 \mathrm{~m}$, $50^{\circ} 40^{\prime} \mathrm{N} 92^{\circ} 58^{\prime} \mathrm{E}, 100 \mathrm{~m}$ from shore, Caragana spinosa, 14.06 .1995 (M. Uusitalo); 1 ( 9 (SZM 001.2554), Kyzyl Dist., ca. $65 \mathrm{~km} \mathrm{~W}$ of Kyzyl in direction to Shagonar, Otukh-Dash, 10.05 .1990 (D.V. Logunov); 3 우 (SZM 001.2538), environs of Kyzyl, Yenisei River Right bank, 700-800 m, p/t and hand picking, 5-7.06.1989 (D.V.Logunov); 1 O (SZM 001.2549), same locality, 20.05.1989 (D.V. Logunov); 3 우 (SZM 001.2559), 3-5 km N of Kyzyl, 700$850 \mathrm{~m}$, Nanophyton erinaceus (dry steppe), 28.05.-2.06.1993 (D.V. Logunov, A.V. Gromov); 1 ㅇ (SZM 001.2546), $3 \mathrm{~km} \mathrm{~N}$ of Kyzyl, Yenisei River Right bank, 700-800 m under stones, 22.07.1989 (D.V. Logunov); 1 O (SZM 001.2553) Tuva, near Kyzyl, right bank of Enisei River, 700-800 m, p/t, 9-20.06.1989 (D.V. Logunov); $1 \sigma^{7} 1$ ( $\mathrm{SZM} 001.2550$ ), Erzin District, ca. 3-5 km E of Erzin, 1000-1100 m, 23-25.05.1990 (D.V. Logunov); 1 ㅇ (SZM 001.2551 ), Erzin District, , ca. $3 \mathrm{~km}$ E of Erzin, butte, 1000-1100 $\mathrm{m}$, among stones, 23.05.1990 (D.V. Logunov, V.V. Dubatolov); 2 우 (SZM 001.2543), Erzin District, $20 \mathrm{~km} \mathrm{~W}$ of Erzin, Ontchalaan Mt. Range, 1100-1300 m, on the Stipa spp., 11-12.08.1988 (D.V. Logunov); $10^{7} 1$ क (SZM 001.2542), Erzin District, $30 \mathrm{~km} \mathrm{~W}$ of Erzin, Yamaalygh Mt. Range, 1200-1300 m, under stones, 910.06.1989 (D.V. Logunov); 1 क (SZM 001.2539), Ovyur Dist., $13-15 \mathrm{~km} \mathrm{~N}$ of Khandagaity Vil., stony steppe on slope, 25.07.1993 


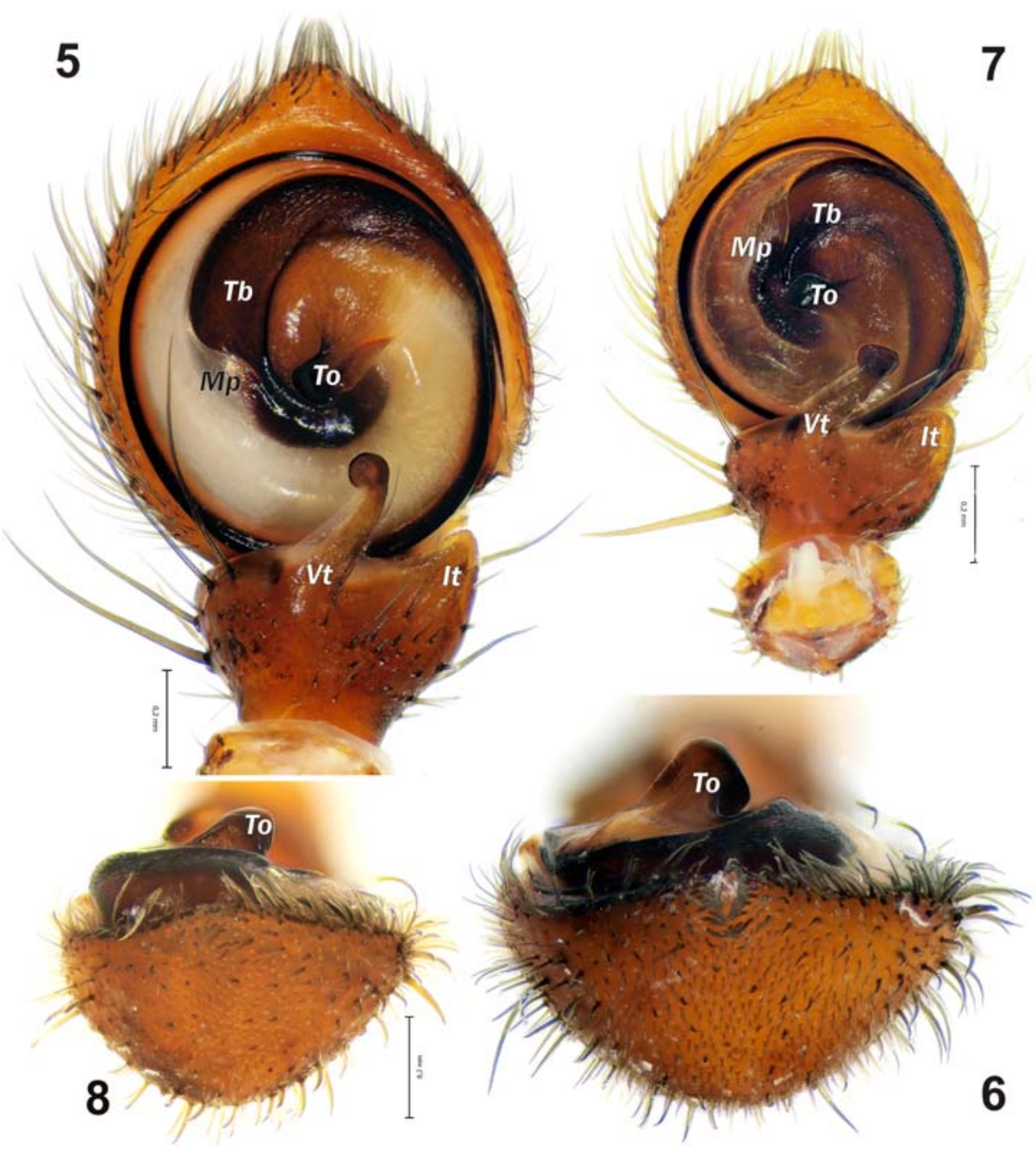

Figs 5-8. Male palps of Xysticus lehtineni sp.n. (5-6, holotype) and X. baltistanus (7-8, Xinjiang). Both to the same scale: 5, 7 ventral; 6, 8 - from above, showing differences in the shape of the tegular outgrowth.

Abbreviations: It - intermediate tibial apophysis; $M p-$ membranous part of the embolus; $T b-$ tegular base; $T o-$ tegular outgrowth; $V t$ - ventral tibial apophysis.

Рис. 5-8. Пальпа самца Xysticus lehtineni sp.n. (5-6, голотип) и X. baltistanus (7-8, Синьцзян) в одном масштабе: 5, 7 - снизу; 6,8 - сверху, показано различие формы выроста тегулюма.

Сокращения: $I t-$ средний отросток голени; $M p$ - мембранизированная часть эмболюса; $T b-$ основание тегулюма; $T o-$ вырост теглюма; $V t$ - вентральный отросток голени.

(D.V. Logunov); 1 O $^{7}$ (SZM 001.2552), SE Tuva, East Tannu-Ola Mt. Range, Aryskannyg-Khem Riv. Canyon, 1250-1350 m, 1618.06.1995 (Yu.M. Marusik); 1 + (SZM 001.2545), Ulug-Khem Dist., 5-7 km E of Shagonar, Khayirkan Mt., under stones, 10.05.1990 (D.V. Logunov); 1 + (SZM 001.2555), Tes-Khem Dist., $10 \mathrm{~km} \mathrm{NW}$ of Khol'-Oozhu, Belengish, 1700-1800 m, steppe, under stones, 9-11.07.1989 (D.V. Logunov).

ETYMOLOGY. The species is named after Pekka T. Lehtinen, honouring his great contribution to arachnology and to the taxonomy of Thomisidae in particular, and on occasion of his $80^{\text {th }}$ birthday.

DIAGNOSIS. The new species is very similar to $X$. baltistanus from which it can be separated by having the typical Xysticus abdominal pattern (Figs 1-3, 2124 ) in all males and most females (in $X$. baltistanus males have white marginal stripes (Fig. 4) and very seldom, a poorly developed pattern, females have no pattern) and by leg spination. Males of Xysticus lehtine$n i$ sp.n. clearly differ from $X$. baltistanus by having 10 11 ventral tibial spines on leg I and 7-10 ventral spines on metatarsus I ( $X$. baltistanus has 7-8 ventral tibial spines and 5-6 on the metatarsus). Females of the new species have $12-17$ ventral tibial spines and 9-15 ventral spines on the metatarsus (X. baltistanus has 10-12 ventral tibial spines and 9-10 ventral metatarsal spines). Males of the new species are larger in body size and carapace (3.55-4.0) in particular (2.7-3.3 in X. baltista$n u s)$. Males of the two species differ also by the size of the palp (Figs 5-14), the different shape of the membranous part of the embolus ( $M p$, Figs $5 \& 7)$, shape and direction of the tegular outgrowth (To, Figs 5-14), 

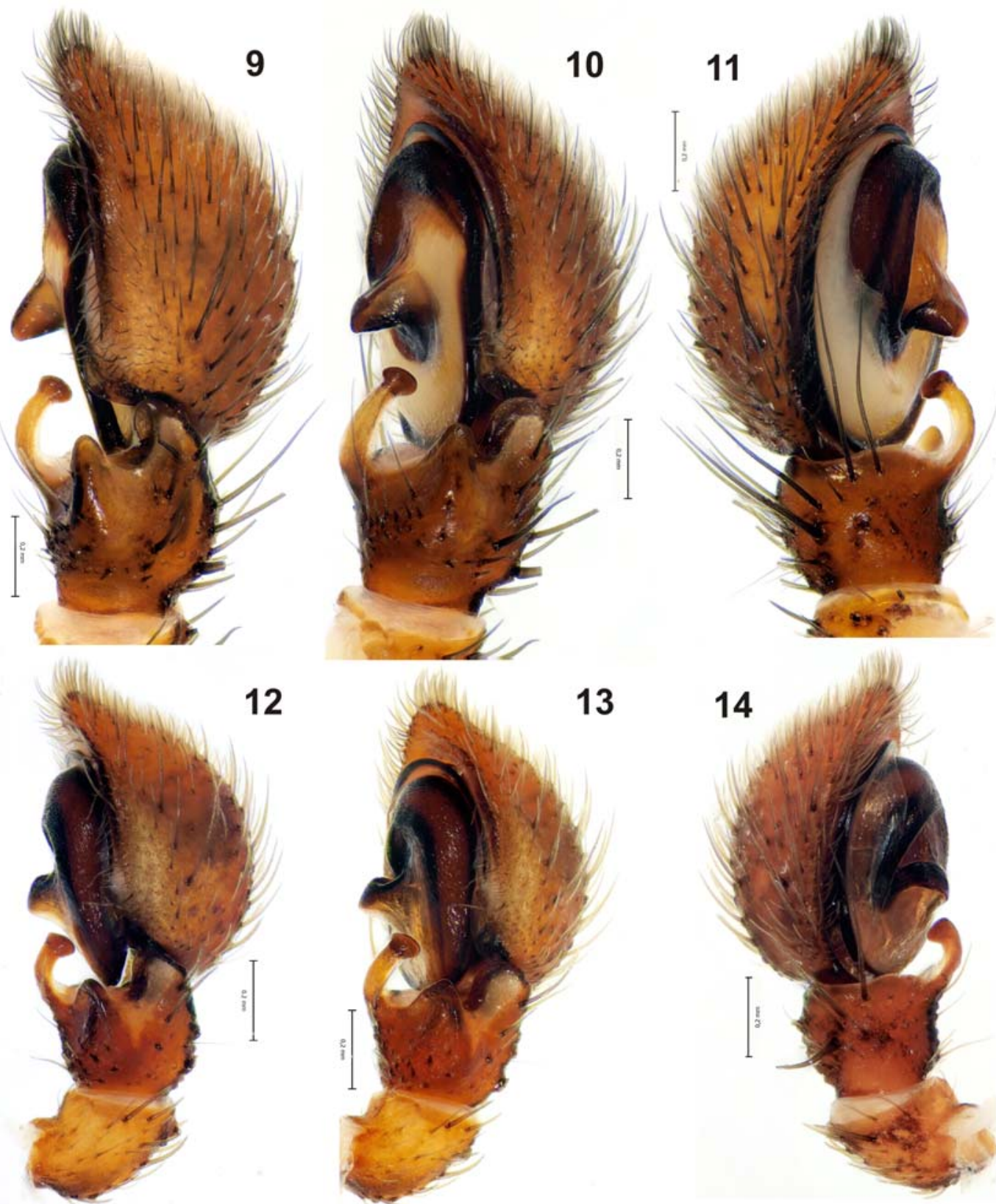

12
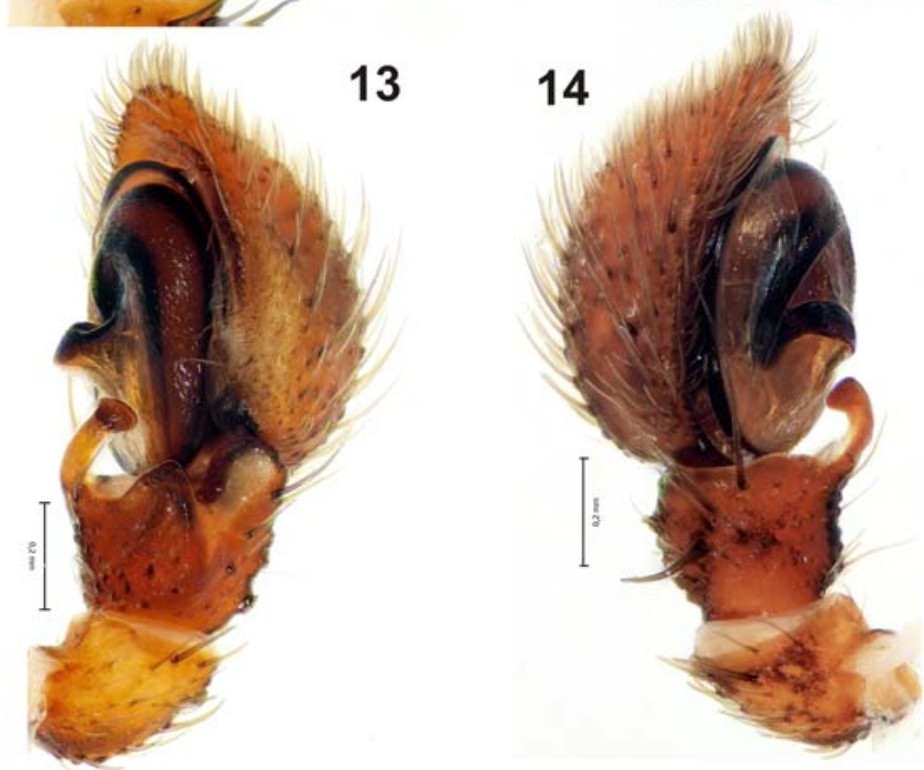

Figs 9-14. Male palps of Xysticus lehtineni sp.n. (9-11, holotype) and X. baltistanus (12-14, Xinjiang). Both to the same scale: $9,12-$ retrolateral; 10,13 - ventro-retrolateral; 11,14 - ventro-prolateral.

Рис. 9-14. Пальпа самца Xysticus lehtineni sp.n. (9-11, голотип) и X. baltistanus (12-14, Синьцзян) в одном масштабе: $9,12-$ ретролатерально; 10, 13 - снизу-ретролатерально; 11, 14 - снизу-провентрально.

as well as in the shape of the intermediate tibial (It) and ventral $(V t)$ apophyses, shape of the tegular base $(T b)$, etc. (Figs 5-14). Females of the two species differ by the shape of the epigynal receptacles: longer and thinner in the new species; shorter and wider in X. baltistanus (cf. Figs 18 \& 20)

DESCRIPTION. Male (holotype). Total length 7.1. Carapace: 3.55 long, 3.4 wide, with dark brown sides, $\mathrm{V}$-shaped light brown figure and brown median band (Fig. 1); posterior declivity dark brown. Abdomen brown, with distinct pattern of white transverse and marginal longitudinal stripes, and blackish stripes as in Fig. 1. Legs light brown, with dark dorsal surfaces and with dark dots at the bases of the setae.

Leg segment lengths: I: $3.95+1.85+3.05+3.15+$ 1.3. II: $3.95+1.8+2.95+3.0+1.25$. III: $2.7+1.25+$ $1.7+1.65+0.85$. IV: $2.75+1.15+1.85+1.9+0.9$.

Spination: I: Fe d0-2-0, p3(4)-0-1(0); Ti p1(0)-1-1, r1-1-1(0), pv5, rv5(6); Mt p2(3)-1-0, r1(2)-0(1)-1(0), 

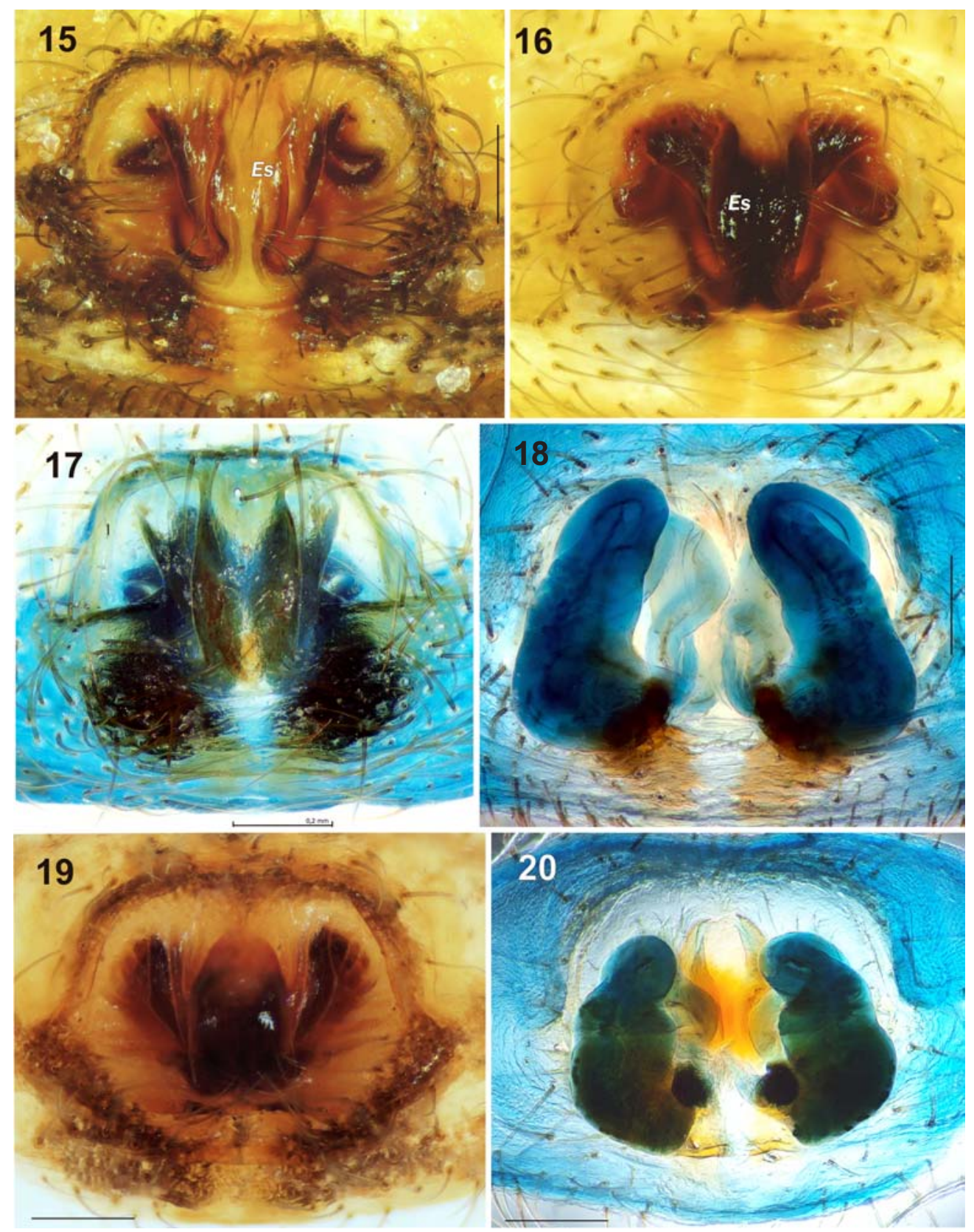

Figs 15-20. Epigyne of Xysticus lehtineni sp.n. (15-18, "allotypes") and X. baltistanus (19-20, Mongolia): 5-16, 19 - intact, ventral; 17 - after maceration, ventral; 18, 20 - dorsal. Scale $0.2 \mathrm{~mm}$. Abbreviation: Es - septum.

Рис. 15-20. Эпигина Xysticus lehtineni sp.n. (15-18, “аллотипы”) и X. baltistanus (19-20, Монголия): 15-16, 19 - интактная, снизу; 17 - после мацерации, снизу; 18, 20 - сверху. Масштаб 0,2 мм. Сокращение: Es - септум.

pv3(5), rv4. II: Fe d0-3-1; Ti p1-1-1, r1-1-1, pv5, rv4; Mt p2-1-0, r1-0-1, pv4, rv4. III: Fe d0-3-1; Ti p1-1-0, r1-0-1, pv3, rv3; Mt p1-1-1, r1-1-1, pv2, rv2. IV: Fe d1-2-1; Pt r1; Ti d1-1-0, p1-0-1, r1-0-1, pv3, rv3; Mt p1-0-1, r1-0-1, pv1, rv1.

Palp as in Figs 5-6, 9-11, with three tibial apophyses, tegulum with central outgrowth (To) directed proximal-prolateral, membranous part of embolus sharply tapering near $T o$.
Female. Total length 12.3. Carapace 4.7 long, 4.25 wide, coloration as in male, but median part wide and posterior declivity yellow. Legs coloured as in male.

Leg segment lengths: I: $4.1+2.3+3.15+2.85+$ 1.2 ; II: $4.1+2.15+3.0+2.8+1.15$; III: $2.9+1.5+$ $1.85+1.6+0.85 ;$ IV: $3.2+1.5+2.05+2.05+0.95$.

Spination: I: Fe p3(2)-0-0; Ti p0(2)-1-1(2), r0-0(1)1(2), pv7(10), rv8(7); Mt p3-2(1)-1, r2(3)-1-2(1), pv7, rv6. II: Fe d0-1-0; Ti p0-1-2, pv7, rv7; Mt p3-0-1, r3- 

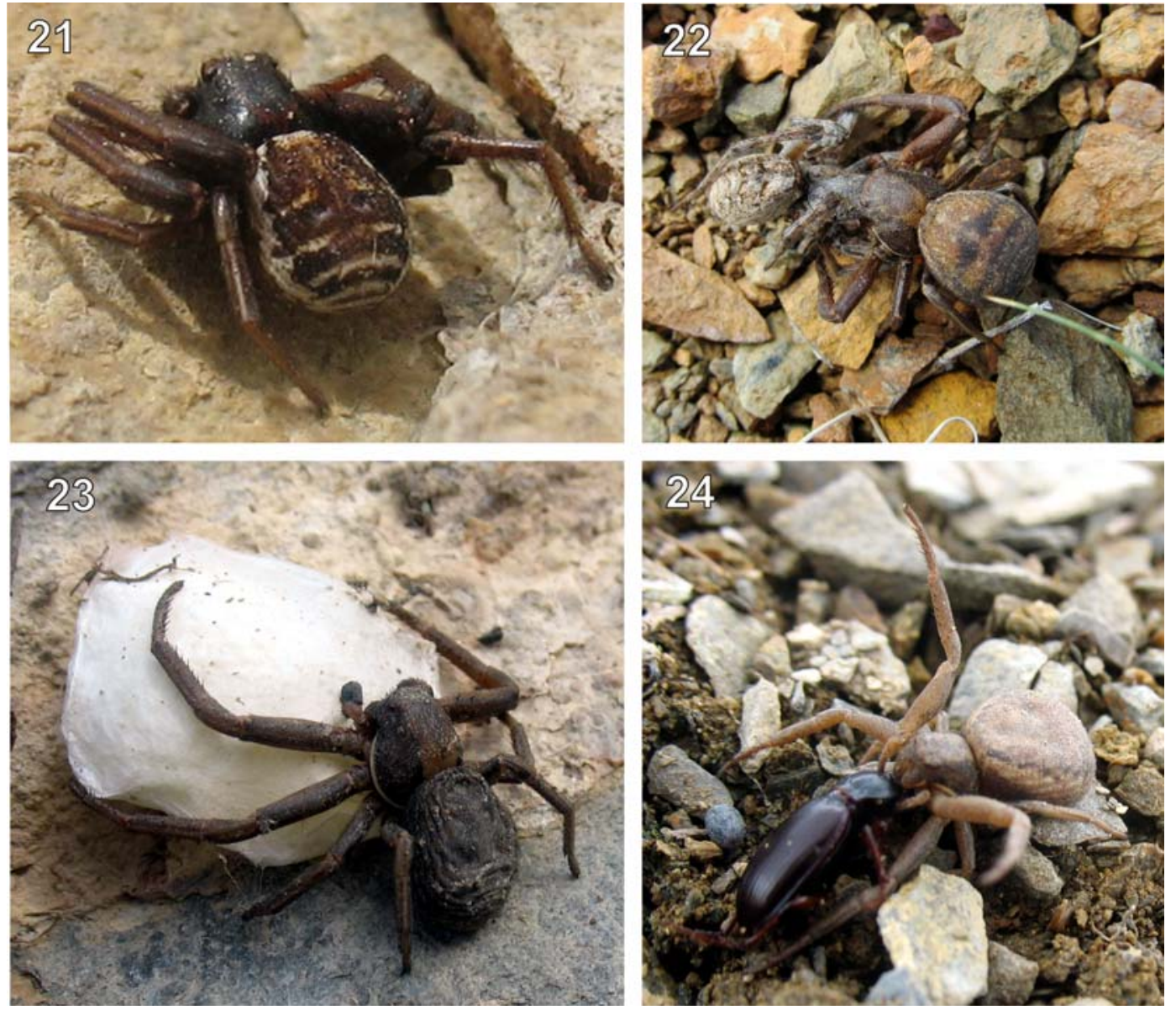

Figs 21-24. Photographs of Xysticus lehtineni sp.n. in nature: 21 - male; 22-24 - female; 22 - eating specimen of Mustelicosa sp. (Lycosidae); 23 - guarding egg-cocoon; 24 - eating a Curtonotus (Carabidae) beetle.

Рис. 21-24. Фотографии Xysticus lehtineni sp.n. в природе: $21-$ самец; 22-24 - самка; 22 - поедает паука-волка из рода Mustelicosa; 23 - охраняет кокон; 24 - поедает жужелицу Curtonotus (Carabidae).

0-1, pv7, rv7. III: Fe d0-1-0; Ti p0-1-1, pv5, rv4; Mt p2-2-2, r2-1-2, pv5, rv2. IV: Fe d0-1-0; Ti d1-1-0, p01-0, pv3, Mt p2-1-1, pv3, rv1.

Epigyne as in Figs 15-18, with well developed septum, elongate receptacles and long insemination ducts.

Variation. Paratype male: total length 7.9, carapace 4.0 long and 3.9 wide. Females vary from 10.6 to 12.3 in body length, carapace 4.0-5.2 long and 3.8-5.0 wide.

BIOLOGY. In the Altai, the new species occurs in mountain stony steppe at elevations of 1100-2500 m. Females are very common and can easily be found under stones. All females seen in July were with eggcocoons (Fig. 23). A single male (the holotype) was found in the Altai at the end of June. It seems that males are short-lived (summer comes to the mountain not earlier than May). Males from Tuva were found at low elevations, from May 23 to June 20. Interestingly, in sibling species the males are much more common than the females, with a ratio of approximately $30: 1$. Such a ratio was observed in the upper flow of the
Kolyma River [Marusik, unpublished data] and in Mongolia - 21:1 [Marusik \& Logunov, 2006]. As shown in Figs 22, $24 X$. lehtineni sp.n. can catch and consume prey (ground beetles and spiders) comparable to their own size.

DISTRIBUTION. The species is currently known from Altai and from various parts of Tuva. It is very likely that some records from Mongolia [Marusik \& Logunov, 2006] refer to this species. One of the records from Mongolia lies in Uvs Aimag, midway between the localities in Altai and Ubsunur Lake.

Xysticus baltistanus (Caporiacco, 1935)

Figs 4, 7-8, 12-14, Map 1.

X. dondalei Marusik, 1988: 1480, f. 7.1-7 (○'+).

X. b.: Marusik et al., 2007: 273, f. 59-60 $\left(\mathrm{O}^{7}\right)$.

For a complete list of references see Platnick [2014].

MATERIAL EXAMINED: CHINA, Xinjiang: 10 (ZMUT), $70 \mathrm{~km} \mathrm{SW}$ of Urumqi, Nantaizi, ca $43.400^{\circ} \mathrm{N} 87.230^{\circ} \mathrm{E}$, June 2004 (N. Fritzén); Hebei Province: $1 \mathrm{O}^{7}$ (HUB), Xinglong County, Wuling Mountain, July 16, 1998 (Wanglu Lie). MONGOLIA, Tov Aimag: $21 \mathrm{O}^{\prime \top} \mathrm{O}^{\top} 1$ ( (ZMMU), Baha-Mukhar, $48^{\circ} 22^{\prime} \mathrm{N} 106^{\circ} 18^{\prime} \mathrm{E}$, 1100 m, 18-23.06.1997 (Y.M. Marusik). RUSSIA: Tuva: 1 ơ 

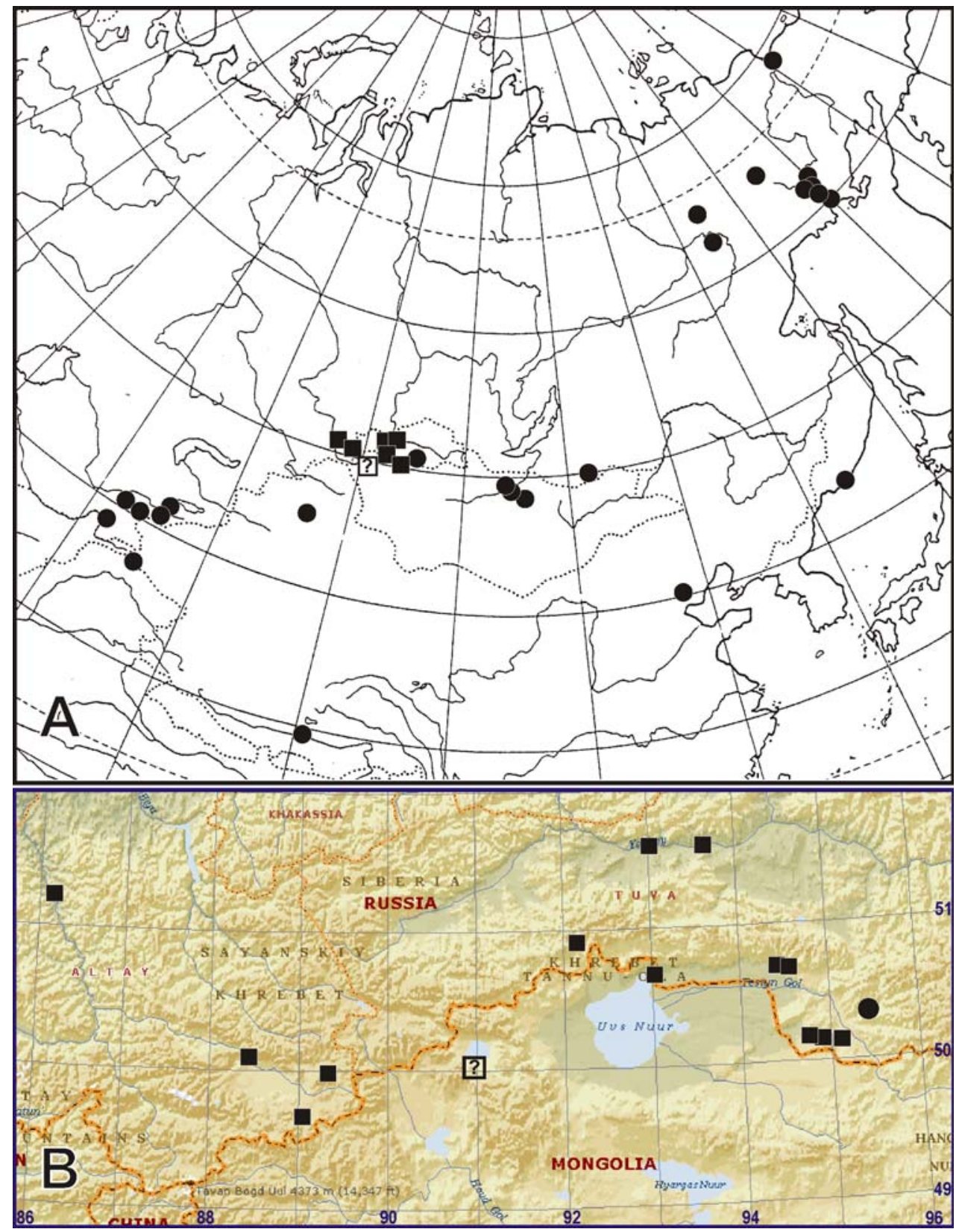

Map 1. Distribution records of Xysticus baltistanus (circle) and X. lehtineni sp.n. (square) in Asia (A) and Altai \& Tuva (B). Карта 1. Находки Xysticus baltistanus (circle) и X. lehtineni sp.n. (square) в Азии (А), Алтае и Туве (В).

(MMUM, G7253.456), Tuva, Sangelen Mt. Range, Dzhen-Aryk (Ck), upper flow, $50^{\circ} 28.50^{\prime} \mathrm{N}, 95^{\circ} 24.74^{\prime} \mathrm{E}, 1750 \mathrm{~m}, 14-18.07 .1996$ (Yu.M. Marusik). Chita Area: $1 \sigma^{7}$ (SZM 001.2557), Kyra Dist., Sokhondo Reserve, confluence of Yernichny Creek and Bukukun River, 1400-1500 m, steppe slope, 28.06.1991 (B.P. Zakharov); 1 + (SZM 001.2547), Kyra Dist., 3-5 km E of Kyra Vil., 900-950 m, stony steppe, 30.05.1991 (D.V. Logunov). Maritime Province: 1 o (SZM 001.2541), Lazo Distr., Kiyevka Vil., mixed forest, 4.06.1976 (T.I. Oliger).

DESCRIPTION. Well described in Marusik [1988]. Here we provide data on spination that was missing in the original description, and size, both characters suitable for species separation.
Male/female. Total length 4.8-6.7, 8.7-10.7. Carapace 2.65-3.3/4.1-4.7 long, 2.5-3.0/3.8-4.4 wide. Spination: Male: I: Fe d0-2(3) -0, p3-1(3)-0; Ti p1-1-1, r1-1-1, pv4, rv4(3); Mt p2-0-1, r1-0-1, pv3, rv3 (from Xinjiang). I: Fe d0-2-0, p3-0-0(1); Ti pv4, rv4; Mt p0$1-0$, r0-1-0, pv3, rv2 (from Mongolia). Female (from Mongolia): I: Fe p2-0-0; Ti p0-0-1, pv8(6), rv4; Mt p21-0, r0-1-1, pv6(5), rv4.

Male palp as in Figs 7-8, 12-14; tegular outgrowth slightly variable and its posterior margin (in ventral view) can be straight, as in Fig. 7, or rounded. Epigyne variable in shape. 
HABITATS. In the upper Kolyma River flow it is one of the most common crab spiders in the study area. Most of the specimens were collected in pitfall traps. Only a few specimens were taken by sweeping and hand picking. Males occur from mid-June. Their peak density was observed in the first week of July. Females can be found from mid-June to late autumn. It inhabits almost all biotopes in the forest belt. The biology of this species is somewhat unclear. While it is a very common species, only a few females (around one dozen) have been collected in the upper Kolyma, whereas the number of males collected was more than 300 . In Mongolia, where spiders were collected by hand picking, the sex ratio was 21 males to 1 female.

DISTRIBUTION: East Palaearctic polyzonal range [Marusik et al., 2000]: from Karakoram Mt Range northeast to the Kolyma River mouth in northeastern Asia (Map 1).

\section{Discussion}

The new species and Xysticus baltistanus belong to the $X$. nigromaculatus-group. This group includes three species in North America: X. durus (Soerensen, 1898) (from Yukon Territory to Greenland and south to Colorado); X. keyserlingi Bryant, 1930 (from Yukon Territory to Mt. Washington and south to New Mexico) and $X$. nigromaculatus Keyserling, 1884 (from Alberta to Manitoba and south to New Mexico), and two species in Asia. The ranges of the Nearctic species overlap, whereas in Asia the two sibling species have allopatric ranges.

ACKNOWLEDGEMENTS. We thank Feng Zhang (Baoding), Shuqiang Li (Beijing), Kirill G. Mikhailov (Moscow), Dmitri V. Logunov (Manchester, UK), Roman Yu. Dudko (Novosibirsk) for providing information and consultations. Special thanks go to Galina N. Azarkina who checked a large amount of material kept in ISEA (Novosibirsk). The following colleagues helped the senior author in several expeditions: S.I. Mishenin, E.Y. Shevnin, A.N. Nakonechnyi (Novosibirsk), R.V. Yakovlev (Barnaul), S.M. and E.M. Ayubaev, Y.A. Novokhatskyi and G.G. Khabiev (Aktash, Russia). S.I. Mishenin provided us with Figs 21, 23-24. The English of the final draft was kindly checked and corrected by David Penney (Manchester). This project was supported in part by the Russian Foundation for Fundamental Research (grant \# 12-04-01548).

\section{References}

Azarkina G.N., Trilikauskas L.A. 2013. New data on spider fauna (Aranei) of the Russian Altai, part III: families Mimetidae, Miturgidae, Oxyopidae, Philodromidae, Pholcidae, Pisauridae, Salticidae, Sparassidae, Tetragnathidae, Theridiidae, Thomisidae, Titanoecidae, Uloboridae and Zoridae // Euroasian Entomol. J. Vol.12. No.3. P.243-254.

Logunov D.V. 1995. Contribution to the northern Asian fauna of the crab spider genus Xysticus C.L. Koch, 1835 (Aranei: Thomisidae) // Arthropoda Selecta. Vol.3. No.3-4. P.111-118.

Logunov D.V., Marusik Yu.M. 1994. A faunistic review of the crab spiders (Araneae, Thomisidae) from the mountains of South Siberia // Bull. Inst. Roy. Sci. Natur. Belgique, Entomologie. T.64. P.177-197.

Logunov D.V., Marusik Yu.M. 1998. A new species of the genus Xysticus from the mountains of South Siberia and Mongolia (Araneae, Thomisidae) // Bull. Br. arachnol. Soc. Vol.11. Pt.3. P.103-106.

Logunov D.V., Marusik Yu.M., Koponen S. 1998. A check-list of the spiders in Tuva, South Siberia with analysis of their habitat distribution // Ber. nat.-med. Verein Innsbruck. Bd.85. P.125159.

Marusik Yu.M. 1988. [New species of spiders from the Kolyma River upper flow] // Zool. Zh. Vol.67. No.10. P.1469-1482 [in Russian, with English summary].

Marusik Yu.M., Logunov D.V. 1990. The crab spiders of Middle Asia, USSR (Aranei, Thomisiade). 1. Descriptions and notes on distribution of some species // Korean Arachnol. Vol.6. No.1. P.31-62.

Marusik Yu.M., Logunov D.V. 1995. The crab spiders of Middle Asia 2 (Arachnida: Araneae: Thomisidae) // Beitr. Araneol. Bd.4 (für 1994). P.133-175.

Marusik Yu.M., Logunov D.V. 2002. New and poorly known species of crab spiders (Aranei: Thomisidae) from South Siberia and Mongolia // Arthropoda Selecta. Vol.10. No.4. P.315-322.

Marusik Yu.M., Logunov D.V. 2006. On the spiders collected in Mongolia by Dr. Z. Kaszab during expeditions in 1966-1968 (Arachnida, Aranei (excluding Lycosidae) // Arthropoda Selecta. Vol.15. No.1. P.39-57.

Marusik Yu.M., Logunov D.V., Koponen S. 2000. Spiders of Tuva, South Siberia. Magadan: IBPN FEB RAS. 252 pp.

Marusik Yu.M., Fritzén N.R., Song D.X. 2007. On spiders (Aranei) collected in central Xinjiang, China // Arthropoda Selecta. Vol.15. No.3. P.259-276.

Platnick N.I. 2014. The world spider catalog, version 14.5. American Museum of Natural History; online at: ttp://research.amnh. org/entomology/spiders/catalog/index.html (accessed February 27, 2014).

Responsible editor K.G. Mikhailov 